|| Print ISSN: 2589-7837 || Online ISSN: 2581-3935 ||

International Journal of Medical Science and Diagnosis Research (IJMSDR)

Available Online at www.ijmsdr.com

NLM (National Library of Medicine ID: 101738824)

Review Article

Volume 5, Issue 1; January: 2021; Page No. 01-12

POTENTIAL TREATMENT OPTION FOR COVID 19 RELATED ANOSMIA - CHAMOMILE (MATRRICARIA CHAMOMILLA) EXTRACT NASAL IRRIGATION - A LITERATURE REVIEW.

\title{
Haider, Romella
}

MBBS. (Pak), LMCC (Alberta, Canada),2nd year PhD Student, School of Traditional Persian Medicine, Qom University of Qom, Iran.

Conflicts of Interest: Nil

Corresponding author: Haider, Romella

DOI: https://doi.org/10.32553/ijmsdr.v5i1.738

\begin{abstract}
:
Corona virus or Covid-19 infection that has rapidly evolved into a global pandemic shortly after its emergence in China in December 2019, demands smart, preventive and treatment recommendations especially related to its early onset symptoms. Anosmia, has now been identified among one of the earliest presenting symptoms in Covid-19 patients. Reports of anosmia in otherwise asymptomatic persons have led to interest in this sign as a potential early indicator of this disease Medical publications about anosmia with COVID-19 are still uncertain of its causative mechanism.

The aim of this review is to provide literature review, as well as evidence-based recommendations for the management of patients with COVID-19 related anosmia, using Chamomile (Matrricaria chamomilla) extract nasal irrigation.

Extensive database search from PubMed, Cochrane library, and Web of science, gray literature searches from Google Scholar, WHO and Traditional Persian Medicine textbook search such as Makhzan al Adwiyehe was performed.

To support the literature, 8 most recent articles published in current year including systematic reviews and metaanalysis as well as clinical trial studies were finally selected to see the effectiveness of Chamomile in treatment of various symptoms of Covid-19.

Chamomile (Matrricaria chamomilla) extract based on its pigenin and Luteolin (causing reduction of leukocyte infiltration), a-Bisabolol (which has anti-inflammatory role), Chamazulene (that provides anti-inflammatory and antipyretic role), Guaiazulene (antipyretic), Matricin (Anti-inflammatory role) and other appreciated roles mentioned in this study may serve as a promising treatment for Covid-19 induced anosmia, especially when used as nasal irrigation.
\end{abstract}

Keywords: Chamomile, Covid-19 related Anosmia, Babouneh, loss of smell.

\section{Introduction:}

Anosmia or loss of smell is broadly defined as olfactory dysfunction(OD). Shortly after the emergence of spectrum of Covid-19 symptoms, an association between Covid-19 and olfactory and gustatory dysfunctions (OGDs) was established (Akosua Adom Agyeman, 2020) ${ }^{\mathrm{i}}$ so much so that high prevalence of OGDs among patients infected with COVID-19 was observed worldwide. In the United Kingdom, a surge in patients seeking medical advice just related to the onset of self-diagnosed loss of sense of smell was reported (Akosua ,2020) $)^{\text {ii }}$. Similarly, an outbreak of olfactory dysfunctions in Iran was observed (Akosua ,2020) iii. In Germany, almost 2 in 3 confirmed reported loss of smell and taste, along with either active or incubatory period of Covid-19. A significant increase in the number of patients presenting with anosmia who otherwise have mild symptoms or in the absence of other symptoms, according to many anecdotal evidences have been reported. In a study of 3191 COVID-19+ patients who were self-isolating at home with mild disease, $15.3 \%$ expressed smell or taste loss (Hopkins, 2020) $^{\text {iv }}$.

As most expected event in the current era of smart communication, an increase in Internet searches for smell-related information in several countries have been on trends every day, as noted by Walker et $\mathrm{al}(2020)^{\mathrm{v}}$ and hypothesize that smell dysfunction 
may be an under-recognized symptom of COVID-19 infection.

Nevertheless, the proportion and characteristics of patients infected with COVID-19 who experience OGDs are not thoroughly understood.

Categorically, this presentation is seen in three different associations:

1. Anosmia without other well reported corona virus symptoms,

2. Anosmia with other well reported corona virus symptoms,

3. Anosmia persisting weeks to months after other, well-reported corona virus symptoms are over.

This study basically focuses on anosmia in groups 2 and 3 associations. Patients with new onset anosmia (group 1) are not target of this study as routine screening of anosmia alone, could contribute to improved case detection in the ongoing COVID-19 pandemic. This might help identify otherwise asymptomatic carriers of disease and trigger targeted testing, although further research is required to identify the proportion of patients in whom new onset anosmia can lead to COVID-19 and whether treating anosmia before the progression of the disease serves to diminish the pandemic load or not.

\section{Methods and materials:}

An extensive database search from PubMed, Cochrane library, and Web of science, gray literature searches from Google Scholar, WHO and Traditional Persian Medicine(TPM) textbook search such as Makhzan Adwiyehe by Khorasani MA. from Noor Jami Tibb, search engine software for TPM resources, Version 1.5 was performed.

Keywords used were "chamomile", and "effects of chamomile on nasal inflammation", "anosmia and chamomile", "mechanism of anosmia in covid-19".

Systematic reviews and meta-analysis as well as clinical trial studies, that were published in last 5 years were studied to see the effectiveness of Chamomile on anosmia, nasal inflammation and allergic symptoms. Finally, 8 most recent studies were selected to show the strong application of this herb in the treatment of various Covid-19 related symptoms.

\section{Main body of article:}

\section{Traditional persian medicine (TPM):}

TPM (humoral medicine) is one of the famous and well recognized medicine, more in-demand nowadays due to its proven applications in various treatments. TPM was established by the four-humor theory (sanguine, phlegm, bile, and melancholy) and disease is based on an imbalance in humors. In early medieval times (Islamic time), Persian traditional physicians (PTPs) were on their peak of practice (Zargaran et al, 2012), ${ }^{\mathrm{vi}}$, (Ahmad et al, 2010) ${ }^{\mathrm{vii}}$. In a very short period over history, these successful practices extended gradually to cover the world (Zargaran et al, 2013) ${ }^{\text {viii }}$. PTPs are the main source of important aspects of medical science by their own observations and skills through > 7000 years of Persian history (Bayan, 2013) ${ }^{\mathrm{ix}}$. The most influential PTPs in history chronologically, were Abu Bakr Muhammad Ebn Zakariya Al-Râzi (Rhazes; 865-925 CE), Ali Ebn AlAbbas-al-Majusi (Haly Abbas; 949-982 CE), Abu Ali Al-Hossein Ebn Abdullah Ebn-e-Sina (Avicenna; 980-1037 CE), and Zinn-ol-Abedin Ismael Jorjani (Sorsanus; 1042-1137 CE). Their most famous books such as, Qanoon fel teb (The Canon) by Ebn-e-Sina, Râzi's Kitab al-hawi(The Continens), Zakhireh Kharazmshahi(The Treasure of Kharazmshah) by Jorjani, and Kitab-al-Maliki (Liber Regius) by HalyAbbas, Makhzan al Advieh ( Treasure of medicines) by Mohamaad Aqili Khorasani have been main reference of Modern medical science from the $13^{\text {th }}$ century to the $19^{\text {th }}$ century (Bayan, 2013) ${ }^{\mathrm{x}}$, (Belen, 2006) ${ }^{\mathrm{xi}}$, (Zarshanas et al,2012) ${ }^{\mathrm{xii}}$, $(\text { Karimi,2013) })^{\text {xiii }}$, (Zarshanas et al,2012) $)^{\text {xiv }}$, (Zarshanas et al,2012) ${ }^{\mathrm{xv}}$,(Zargaran, 2012) (xvi $^{\mathrm{x}}$.

\section{Mechanism of anosmia in modern medicine and TPM:}

\section{A) According to Modern Medicine:}

The exact mechanisms underlying Anosmia among patients with COVID-19 infection remain unclear (Meng et al, 2020) ${ }^{\mathrm{xvii}}$. However, olfactory impairment after upper respiratory tract infection is a common occurrence in clinical settings. In particular, post viral olfactory dysfunction (PVOD) has been implicated in $40 \%$ of cases of anosmia in adults, (Hopkins et al, $2020)^{\text {xviii }}$ with coronaviruses accounting for $10 \%$ to $15 \%$ of cases (Akosua ,2020) ${ }^{\mathrm{xix}}$. OD in COVID-19 infection could be related to the involvement of the olfactory bulb or to peripheral damage of the olfactory receptor cells in the nasal neuro-epithelium $\left(\right.$ Butowt,2020) ${ }^{\mathrm{xx}}$. This assertion is based on the potential neurotrophic features of SARS-CoV-2. In particular, it has been demonstrated in transgenic mice that after intranasal administration of SARS-CoV (which shares similarities with SARS-CoV-2), the virus could penetrate into the brain through the 
olfactory bulb, leading to rapid trans-neuronal spread (Akosua ,2020) ${ }^{\mathrm{xxi}}$.

\section{B) According to TPM:}

In TPM, loss of olfactory function is called as AlKhashm, which is defined as:

"Khashm means either complete loss or decrease in power of smell. It occurs in two forms: either both good and bad smell is lost or one of the two is lost. In both of these presentations, it could be either congenital which is incurable, or it could be acquired. Acquired one can be due to: an obstruction, and/or humoral imbalance. Obstruction might occur in nasal cavity and can be due to a swelling, or tumor, or redundant flesh growth, or thick humoral fluid or due to narrowing of the nasal cavity from birth or due to trauma or fall causing bone problem or this obstruction might occur in bony holes due to thick sticky humoral fluid or humoral imbalance, or this obstruction can occur in anterior brain or both hemispheres of brain or elsewhere.. "xxii.

Nazim Jahan MA. Exir-e Azam (Great Elixir) vol 1 page 511

Comparing the two resources, it can be obtained that involvement of the olfactory bulb or to peripheral damage of the olfactory receptor cells in the nasal neuro epithelium as described as a possible mechanism of Anosmia in Modern Medicine, is explained in similar fashion, but in different words in TPM by mentioning that, obstruction might occur in nasal cavity and can be due to a swelling, or tumor, or redundant flesh growth, or thick humoral fluid or due to narrowing of the nasal cavity.

In both cases, there seems to be involvement of a foreign material that has disturbed the olfactory reception physically by initiating a sequential process, which is either inflammatory or immune related or direct viral interruption. Since the mechanism is yet unclear, all known above processes must be countered to effectively able to treat the problem.

Diversity in the selection of drugs with different modes of action in Modern medicine and incapability of treating the cause completely due to side effects of such drugs is another reason to involve the use of TPM drugs. Options such as Chamomile, discussed in this study is ideal in this case, as not only various modes of action of this herb counter most of the etiological processes involved in OD due to Covid-19, but also because it is one of the safest drug used in various diseases (Vasyl,2019) xxiii.

TREATMENT OF ANOSMIA IN MODERN AND TPM:
A) Treatment of Anosmia in Modern Medicine:

Although stepwise efforts have been made in the form of recommendations for potential treatment options for OD related to Covid-19, such as olfactory training, different medical treatment options, referral guidelines and imaging for patients with COVID-19 related anosmia (Hopkins,2020) ${ }^{\mathrm{xxiv}}$, the guidelines are in continuous state of evolving as experience of COVID19 develops.

For example, according to BRS guidelines, olfactory training was recommended for all patients with persistent anosmia of more than 2 weeks' duration, and oral steroids, steroid rinses and omega-3 supplements were to be considered on an individual basis. Recommendations were made regarding the need for referral and investigations.

Nevertheless, Owing to the high occurrence of anosmia in COVID-19-positive individuals, the indiscriminate use of corticosteroids, particularly in the absence of known head trauma or allergic symptoms, should be discouraged because corticosteroids may escalate COVID-19 infection $\left(\right.$ Akosa,2020) ${ }^{\mathrm{xxv}}$.

\section{B) Treatment of Anosmia in TPM:}

As mentioned above, the cause of Anosmia in TPM is mainly an obstruction which in case of this ailment, mostly seems to be related to presence of abnormal thick body humor.

This abnormal body humor has resulted in series of changes(infection), locally and to wherever it had access to, and has ultimately resulted in anosmia.

Although this is not as simple as its inferred here, rather a whole set of theory stands behind this pathology, but this study is limited to offer only potential recommendation of anosmia rather than its pathology.

The management of anosmia, according to TPM is summarized in two sequential steps:

1. Talteef and Tehleel- Two treatment processes in TPM that involves softening (talteef) and then removal (tehleel) of (obstruction which is an) abnormal thick body humor

2. Daff e afoonat (anti-oxidant, antimicrobial and anti-inflammatory) Treat the series of changes that has been caused by this obstruction.

\section{Chamomile (Matrricaria Chamomilla):}

Chamomile (Matricaria chamomilla L.) is a wellknown medicinal plant species from the Asteraceae family often referred to as the "star among medicinal species." Nowadays it is a highly favored and much used medicinal plant in folk and traditional medicine. Chamomile (Matricaria chamomilla L.) is one of the 
important medicinal herb native to southern and eastern Europe. It is also grown in Germany, Hungary, France, Russia, Yugoslavia, and Brazil ${ }^{\mathrm{xxvi}}$.

The plant grows $15-60 \mathrm{~cm}$ tall, with an erect stem and leaves that divide up to three times along the stem. Chamomile blooms in early to midsummer. The flowers are positioned at the apical part of the plant, with a yellow central area and wide white petals.

\section{Chamomile (Matrricaria chamomilla) as per TPM resources:}

Babunej, or Babouneh, is one of the most widely used drug in TPM for various ailments and prevention of them. The nature of this herb is: warm and dry $(\text { Aghili) })^{\text {xxvii }}$.

The characteristics of the herbs in TPM are studied under two main headings:
1. General characteristics: These are the characteristics of an herb that benefit the whole body, not focusing any single organ.

2. Organ- specific characteristics: These are the characteristics that benefit one or few organs specifically (Aghili) ${ }^{\mathrm{xxviii}}$.

Few most important general characteristics of Babouneh are:

a) Mulatif :Softner of thick abnormal humors

b) Mohallel be jazb: Remover of abnormal humors from the body, without self being absorbed.

c) Mofatteh: opener of blockages, obstruction from the various channels of body.

d) Musseel: Mover of the stagnant thick humor of body by heating them up

e) Mulleyin: Laxative

f) Murakhi: Softner of thickness of various organs.

Various general and organ specific characteristics of

Bobuneh are summarized in table 1.

\section{Table 1: General and organ specific characteristics of Bobuneh as per TPM ${ }^{\mathrm{xxix}}$}

Characteristics of Chamomilla Matricaria as per TPM

Mulatif: Softner

Mohallel be Jazb: Remover without self being absorbed

Mofatteh: Opener of blockages/obstructions

Muqawi Dimaagh wa Aasaab wa baah: tonic for brain and nerves and reproductive function

Tiryaqiyyat: General antidote

Muddir: Increases the secretion of sweat, milk, urine and menstruation

Tehleel: Removal of remnants of ramd (eye ailment)

Tehleel: Removal of flatulence of ear

Beneficial in cerebral diseases, Headache, catarrh, Asthma, Jaundice, chest pain, amenorrhea.

Tehleel and Taleen of swellings of these organs : Liver, uterus, testis, anus and bladder

Expulsion of Mashimeh: Removal of placenta after delivery

Daff e afoonat: Removing infection caused by soda(black bile humor) and balgham(Phlegm)

Anti pyretic

Anti Colic

Beneficial in ileus

Beneficial in Assar al-Bol :Urinary retention and hesitancy and

Assar wiladat: difficult labor and

Gerb Rutab: wet skin rashes and

Clears the body of abnormal humors

Taking steam of cooked chamomile or with vinegar relieves catarrh

Washing the eye with chamomile water is good for eye pain and

Using boiled chamomile relieves nasal inflammation 
B) Chamomile (Matrricaria chamomilla) as per Modern medicine:

The chamomile as a herbal product for treatment of various diseases is enlisted in the pharmacopoeia of 26 countries $^{\mathrm{xxx}}$. Utilization of chamomile for use in flatulence, colic, hysteria, and intermittent fever has been known since years (Singh, 2011) ${ }^{\mathrm{xxxi}}$. Chamomile is generally beneficial through its anti-inflammatory and antiseptic, as well as its anti-spasmodic and mildly sudorific effects (Merecili,1990) ${ }^{\text {xxii }}$.

In Digestion: Particularly, it is used for digestion in various ways. For e.g., it is used as a tisane (preparation of one spoon of it in a liter of cold water without warming it) for stomachaches, slow digestion, diarrhea and nausea (Singh, 2011) ${ }^{\text {xxxiii }}$. M. chamomilla infusion produced a marked stimulatory action on the secretary function of the liver(Pasechnik) $)^{\text {xxxiv }}$

In Urinary and Reproductive system: Chamomile is used effectively for inflammation of the urinary tract and for painful menstruation (Singh, 2011) ${ }^{\mathrm{xxxv}}$.

External uses: Externally, the drug in powder form may be applied to wounds slow to heal, for skin eruptions, and infections, such as shingles and boils, also for hemorrhoids (Fluck, 1988) ${ }^{\mathrm{xxxvi}}$.

ENT uses: It is a potent drug for inflammation of the mouth, throat, and the eyes (Fluck, 1988) xxxvii $^{\text {. }}$

In Cardiac disease: Hemodynamic effects of chamomile tea in patients with cardiac disease has also been found (Gould et al.) xxxviii $^{\text {. }}$

Tranquilizer: Patients with sleep disorders fell into deep sleep after taking the beverage(Singh, 2011) ${ }^{\text {xxxix }}$.

Various other benefits of the herb are mentioned in table 2.

Chemical Composition: M. chamomilla comprises of therapeutically active compound classes. Sesquiterpenes and polyacetylenes as well as flavonoids and coumarins, are most important chemical components(Schilcher,1987) ${ }^{\mathrm{xl}}$. More than ten of phenol derived compounds found in chamomile extract which are biologically active are luteolin and luteolin-7-O-glucoside (flavones), chlorogenic acid and caffeic acid (phenylpropanoids), herniarin and umbelliferone (coumarin), apigenin, apigenin7-Oglucoside, quercetin and rutin (flavonols), and naringenin (flavanone)(Gupta et al. 2010) ${ }^{\mathrm{xli}}$.

Besides the main constituents, secondary metabolites (Pino, 2002) ${ }^{\text {xlii }}$, (Pirzad et al. 2002) ${ }^{\text {xlii }}$ contain 36 flavonoids(Exner,1980) ${ }^{\text {xliv }}$, 28 terpenoids, and more than 50 additional compounds with potential pharmacological activity. Antimicrobial components are in the form of $\alpha$-bisabolol and fungistatic components are in the form of cyclic ethers ${ }^{x l v}$ which is umbelliferone, whereas chamazulene and $\alpha$-bisabolol are antiseptic (Singh, 2011) ${ }^{\mathrm{xlvi}}$. The chamomile was found to have the most effective anti-leishmanial activity (Shnitzler,1996) ${ }^{\mathrm{xlvii}}$.

The main constituents of the flowers also include several phenolic compounds, primarily the flavonoid apigenin, quercetin, patuletin, luteolin, and their glucosides. Besides the capitula, the shoot (leaves and stem) and root of the plant also contain essential oil. The presence of (Z)-3-hexenol, $\alpha$-farnesene, germacrene $\mathrm{D},(\mathrm{E})$-nerolidol, spathulenol, hexadec-11yn-11,13-diene, (E)- $\beta$ farnesene and (Z)- and (E)-enyn-dicycloethers, were reported in earlier investigations on the oil of this herb (Wagner) ${ }^{\text {xlviii }}$, whereas the oil extracted from the roots contains linalool, nerol, geraniol, $\beta$-elemene, (E)- $\beta$-farnesene, $\alpha$-farnesene, spathulenol, $\tau$-cadinol, $\tau$-muurolol, $\beta$ caryophyllene, cis-caryophyllene, caryophyllene oxide, chamomillol, hexadec-11-yn-11,13-diene, cisand trans-en-yn-dicycloethers, and chamomile esters I and II (Reichling, 1983) $)^{\text {xlix }}$.

a-Humulene, hexadec-11-yn-13,15-diene, phytol, isophytol, and methyl palmitate were detected for the first time from M. chamomilla (Kumar et al., 2001).

Table 2: General and organ specific characteristics of Bobuneh as per Modern Medicine

\begin{tabular}{ll}
\hline Characteristics OF Chamomilla Matricaria as per Modern Medicine \\
\hline Characteristics & References \\
\hline Analgesic & li \\
\hline Antiallergic & lii \\
\hline Anticancer & liii \\
\hline Antihyperglycemic & liv \\
\hline Antiinflammatory & lv \\
\hline
\end{tabular}




\begin{tabular}{|c|c|}
\hline Antipruritic & lvi \\
\hline Antimicrobial & \begin{tabular}{ll|} 
Ivii \\
\end{tabular} \\
\hline Antisolar & Tviii \\
\hline Antistress & lix \\
\hline Antispasmodic & $\mathrm{Ix}$ \\
\hline Antiulcer & Ixi \\
\hline Anxiolytic & Ixii \\
\hline GI disorders & Ixiii \\
\hline Hepato-protectivity & Ixiv \\
\hline Immunomodulatory & $\mathrm{Txv}$ \\
\hline Anti-polio & Ixvi \\
\hline Intracranial irrigate & Txvii \\
\hline Ovicidal, repellent & Ixviii \\
\hline Antiosteoporosis & Ixix \\
\hline Sedative & Ixx \\
\hline Infant botulism & Ixxi \\
\hline Oral mucositis & Ixxii \\
\hline Uterotonic & Txxiii \\
\hline Virucidal & Txxiv \\
\hline Wound healer & Txxy \\
\hline
\end{tabular}

Recent studies in 2020 showing Chamomile effectiveness in Covid-19 related symptoms:

Systematic reviews and meta-analysis as well as clinical trial studies, that were published in last 5 years were studied to see the effectiveness of Chamomile on anosmia, nasal inflammation and allergic symptoms. Finally, 8 most recent studies were selected to show the strong application of this herb in the treatment of various Covid-19 related symptoms.

Table 3: Recent studies in 2020 showing Chamomile effectiveness in Covid-19 related symptoms

\begin{tabular}{|c|c|c|c|c|c|}
\hline No & Article & Study type & Year & $\begin{array}{l}\text { Form of } \\
\text { Chamomila } \\
\text { used }\end{array}$ & Journal \\
\hline 1. & $\begin{array}{l}\text { Predicted therapeutic targets for COVID-19 } \\
\text { disease by inhibiting SARS-CoV-2 and its } \\
\text { related receptors }\end{array}$ & $\begin{array}{r}\text { Molecular } \\
\text { docking }\end{array}$ & 2020 & Chamomile herb & $\begin{array}{l}\text { Informatics in } \\
\text { Medicine Unlocked }\end{array}$ \\
\hline 2. & $\begin{array}{l}\text { Effects of Chamomile extract nasal drop and } \\
\text { chronic rhinosinusitis treatment } \text { txxvii }^{\text {and }}\end{array}$ & $\begin{array}{l}\text { double blind } \\
\text { study }\end{array}$ & 2020 & $\begin{array}{l}\text { chamomile } \\
\text { extract }\end{array}$ & $\begin{array}{l}\text { American Journal of } \\
\text { Otolaryngology }\end{array}$ \\
\hline 3. & $\begin{array}{l}\text { Novel SARS-CoV-2 and COVID-2019 } \\
\text { Outbreak: Current Perspectives on Plant- } \\
\text { Based Antiviral Agents and Complementary } \\
\text { Therapy }\end{array}$ & $\begin{array}{l}\text { Literature } \\
\text { review }\end{array}$ & 2020 & Chamomile herb & $\begin{array}{l}\text { Indian Journal of } \\
\text { Pharmaceutical } \\
\text { Education } \\
\text { Research }\end{array}$ \\
\hline 4. & $\begin{array}{l}\text { Clinically improvement in a Case } \\
\text { of COVID-19 with Gastrointestinal } \\
\text { Manifestations through Using Natural } \\
\text { Therapy based on Persian Medicine }{ }^{\text {lxxix }}\end{array}$ & Case report & 2020 & $\begin{array}{l}\text { chamomilla } \\
\text { extract }\end{array}$ & $\begin{array}{l}\text { Traditional and } \\
\text { Integrative Medicine }\end{array}$ \\
\hline 6. & $\begin{array}{l}\text { Quantitative proteomics analysis of the } \\
\text { treatment of asthma rats with total flavonoid } \\
\text { extract from chamomile }\end{array}$ & $\begin{array}{l}\text { Quantitative } \\
\text { proteomics } \\
\text { analysis }\end{array}$ & 2020 & $\begin{array}{l}\text { Extraction of } \\
\text { total flavonoids } \\
\text { from chamomile }\end{array}$ & Biotechnol Lett (2020) \\
\hline 7. & $\begin{array}{l}\text { Promising preventive and therapeutic effects } \\
\text { of TaibUVID nutritional supplements for } \\
\text { COVID-19 pandemic: towards better public } \\
\text { prophylaxis and treatment }{ }^{1 \times x x i}\end{array}$ & $\begin{array}{l}\text { A retrospective } \\
\text { study }\end{array}$ & 2020 & & $\begin{array}{l}\text { American Journal of } \\
\text { Blood Research }\end{array}$ \\
\hline 8. & $\begin{array}{l}\text { COVID-19 Pandemic, Unani Medicine and } \\
\text { Immunomodulation }\end{array}$ & $\begin{array}{l}\text { Literature } \\
\text { review }\end{array}$ & 2020 & Cham & te.net \\
\hline
\end{tabular}




\section{Why in the form of nasal irrigation?}

It is well established that Covid-19 pandemic has affected daily lives of many people of the world, most of which is attributed to its psychological effects. Fact that $\mathrm{OD}$ is directly related to the nose and besides its medicinal treatment effectiveness, saline nasal irrigation may serve as a source of psychological relief for patients suffering from Anosmia.

Saline nasal irrigation appears safe, with no reported serious adverse events (Rabago, 2009) ${ }^{\text {lxxxiii. }}$. Saline nasal irrigation is an adjunctive therapy for upper respiratory conditions that bathes the nasal cavity with spray or liquid obtained after boiling the herbal extract. Consensus guidelines recommend saline nasal irrigation as a treatment for a variety of other conditions.

Common disorders that negatively affect patients' quality of life. Saline nasal irrigation is an adjunctive therapy for upper respiratory conditions, likely originating in TPM (Aghili) ${ }^{\text {lxxxiv }}$. Its use, including indications, solutions, and administration devices, was first described in medical literature in the early 12th century (Aghili) ${ }^{\operatorname{lxxx}}$. Saline nasal irrigation is an effective management strategy for many sino-nasal conditions (Brown,2004) (xxxii $^{\text {lxx }}$ In survey of 330 family physicians, 87 percent reported recommending it to their patients for one or more conditions (Rabago, 2009) $)^{\mathrm{lxx} x v i i}$.

Nasal irrigation is performed by instilling medical liquid obtained by boiling and then sieving Chamomile herb, into one nostril and allowing it to drain out of the other nostril, bathing the nasal cavity. It can also be performed with low positive pressure from a spray or squirt bottle, or with gravity-based pressure using a vessel with a nasal spout, such as a neti pot. Both are available over the counter.

\footnotetext{
i Akosua Adom Agyeman, Ken L. Chin, Cornelia B. Landersdorfer, Danny Liew, Richard Ofori-Asenso, Smell and Taste Dysfunction in Patients With COVID-19: A Systematic Review and Meta-analysis,

Mayo Clinic Proceedings,Volume 95, Issue 8,2020,Pages 1621-1631,ISSN 0025-6196, https://doi.org/10.1016/j.mayocp.2020.05.030.

ii Akosua Adom Agyeman, Ken L. Chin, Cornelia B. Landersdorfer, Danny Liew, Richard Ofori-Asenso, Smell and Taste Dysfunction in Patients With COVID-19: A Systematic Review and Meta-analysis,
}

\section{Mechanism of Action of nasal irrigation:}

The exact mechanism of action of nasal irrigation is unknown. One possibility is that the breakdown of the protective function of the nasal mucosa plays a role in upper respiratory conditions. Saline nasal irrigation may improve nasal mucosa function through several physiologic effects, including direct cleansing $\left(\right.$ Karadag,2002) ${ }^{\text {lxxxviii }},(\text { Kurtaran ,2003) })^{\text {lxxxix }}$; removal of inflammatory mediators (Kephart et al. ,2005) ${ }^{\mathrm{xc}},\left(\right.$ Georgitis ,1994) ${ }^{\mathrm{xci}}$; and improved mucociliary function, as suggested by increased ciliary beat frequency $(\text { Boek }, 2002)^{\text {xcii }},(\text { Talbot }, 1997)^{\text {xciii }}$.

\section{Conclusion:}

After defining Anosmia according to TPM and Modern Medicine, and reviewing its treatment mechanisms in both medicines, a comprehensive study was conducted about diverse and extensive characteristics of Chamomile Matricaria L. 8 current studies relating direct role of Chamomile in treatment of Covid 19 on different symptoms were also discussed. Based on various and effective properties of Chamomile M. as anti- inflammatory, anti- viral, anti- spasmodic, tehleel (analyzer/ softner), taqteeh (remover of obstacles), etc. as studied both in TPM and Modern Medicine, this study revealed a promising predictive role of this herb to be a potential treatment drug in Covid-19 related Anosmia, especially when used as a nasal irrigation.

Relying on the above extensive study, further clinical and evidence based trials can hopefully pave the way of this treatment option in Covid-19 related Anosmia patients soon.

\section{References:}

Mayo Clinic Proceedings,Volume 95, Issue 8,2020,Pages 1621-1631,ISSN 0025-6196, https://doi.org/10.1016/j.mayocp.2020.05.030.

iii Akosua Adom Agyeman, Ken L. Chin, Cornelia B. Landersdorfer, Danny Liew, Richard Ofori-Asenso, Smell and Taste Dysfunction in Patients With COVID-19: A Systematic Review and Meta-analysis,

Mayo Clinic Proceedings,Volume 95, Issue 8,2020,Pages 1621-1631,ISSN 0025-6196,

https://doi.org/10.1016/j.mayocp.2020.05.030. 
${ }^{\text {iv }}$ Hopkins, Claire \& Surda, Pavol \& Kumar, Bn. (2020). Presentation of New Onset Anosmia During the COVID-19 Pandemic. Rhinology. 58. 10.4193/Rhin20.116.

$\checkmark$ Akosua Adom Agyeman, Ken L. Chin, Cornelia B. Landersdorfer, Danny Liew, Richard Ofori-Asenso, Smell and Taste Dysfunction in Patients With COVID-19: A Systematic Review and Meta-analysis,

Mayo Clinic Proceedings,Volume 95, Issue 8,2020,Pages 1621-1631,ISSN 0025-6196, https://doi.org/10.1016/j.mayocp.2020.05.030.

vi A. Zargaran, M.M. Zarshenas, A. Mehdizadeh, A. Mohagheghzadeh,Oxymel in medieval Persia, Pharm Hist, 42 (2012), pp. 11-13,

vii S. Ahmad, S. Rehman, A.M. Ahmad, et al.Khamiras, a natural cardiac tonic: an overview

J Pharm Bioallied Sci, 2 (2010), pp. 93-99

CrossRef ViewRecord in Scopus Google Scholar

viii A. Zargaran, M.M. Zarshenas, A. Karimi, H.

Yarmohammadi, A. Borhani-HaghighiManagement of stroke as described by Ibn Sina (Avicenna) in the Canon of Medicine Int J Cardiol, 169 (2013), pp. 233-237 View Record in Scopus Google Scholar

ix L. Bayan, S.M. Modarres Mousavi, A. Gorji, History of Neurological Disorders in Persian Medicine

J Res Hist Med, 2 (2013), pp. 115-127

View Record in Scopus Google Scholar

${ }^{x}$ L. Bayan, S.M. Modarres Mousavi, A. Gorji, History of Neurological Disorders in Persian Medicine

J Res Hist Med, 2 (2013), pp. 115-127

View Record in Scopus Google Scholar

xi D. Belen, A. AcidumanA pioneer from the Islamic Golden Age: Haly Abbas and spinal traumas in his principal work, The Royal Book

J Neurosurg Spine, 5 (2006), pp. 381-383

CrossRef View Record in Scopus Google Scholar

xii A. Zargaran, A. Mehdizadeh, M.M. Zarshenas, A. MohagheghzadehAvicenna (980-1037 AD) J Neurol, 259 (2012), pp. 389-390 CrossRef View Record in Scopus Google Scholar

xiii A. Karimi, A. Zargaran, A. Borhani-HaghighiAvicenna's description of Willis circle

Int J Cardiol, 168 (2013), p. 3041

View Record in Scopus Google Scholar

xiv A. Zargaran, A. Mehdizadeh, M.M. Zarshenas, A. MohagheghzadehAvicenna (980-1037 AD) J Neurol, 259 (2012), pp. 389-390
CrossRef View Record in Scopus Google Scholar

xv A. Zargaran, A. Mehdizadeh, M.M. Zarshenas, A. MohagheghzadehAvicenna (980-1037 AD) J Neurol, 259 (2012), pp. 389-390 CrossRef View Record in Scopus Google Scholar

xvi M.M. Zarshenas, A. Mehdizadeh, A. Zargaran, A. MohagheghzadehRhazes (865-925 AD) J Neurol , 259 (2012), pp. 1001-1002 CrossRef View Record in Scopus Google Scholar

xvii Meng X, Deng Y, Dai Z, Meng Z. COVID-19 and anosmia: A review based on up-to-date knowledge. Am J Otolaryngol. 2020;41(5):102581. doi:10.1016/j.amjoto. 2020.102581

xviii Hopkins, C., Surda, P., Whitehead, E. et al. Early recovery following new onset anosmia during the COVID19 pandemic - an observational cohort study. $J$ of Otolaryngol - Head \& Neck Surg 49, 26 (2020). https://doi.org/10.1186/s40463-020-00423-8

xix Akosua Adom Agyeman, Ken L. Chin, Cornelia B. Landersdorfer, Danny Liew, Richard Ofori-Asenso, Smell and Taste Dysfunction in Patients With COVID-19: A Systematic Review and Meta-analysis,

Mayo Clinic Proceedings,Volume 95, Issue 8,2020,Pages 1621-1631,ISSN 0025-6196,

https://doi.org/10.1016/j.mayocp.2020.05.030.

${ }^{x x}$ Butowt R, von Bartheld CS. Anosmia in COVID-19: Underlying Mechanisms and Assessment of an Olfactory Route to Brain Infection. The Neuroscientist. September 2020. doi:10.1177/1073858420956905

xxi Akosua Adom Agyeman, Ken L. Chin, Cornelia B. Landersdorfer, Danny Liew, Richard Ofori-Asenso, Smell and Taste Dysfunction in Patients With COVID-19: A Systematic Review and Meta-analysis,

Mayo Clinic Proceedings,Volume 95, Issue 8,2020,Pages 1621-1631,ISSN 0025-6196, https://doi.org/10.1016/j.mayocp.2020.05.030.

xxii Nazim Jahan MA. Exir-e Azam (Great Elixir). Tehran: Institute of Medical History, Islamic Medicine and Complementary Studies, Iran University of Medical Sciences; 2008. Vol 1 page 511.

xxiii Vasyl Popovych, Ivana Koshel, Alexander Malofiichuk, Lyubov Pyletska, Alexander Semeniuk, Oksana Filippova, Ruslana Orlovska,A randomized, open-label, multicenter, comparative study of therapeutic efficacy, safety and tolerability of BNO 1030 extract, containing marshmallow root, chamomile flowers, etc.in the treatment of acute nonbacterial tonsillitis in children aged 6 to 18 years,American 
Journal of Otolaryngology,Volume 40, Issue 2,2019,Pages 265-273,ISSN 0196-0709,

https://doi.org/10.1016/j.amjoto.2018.10.012.

xxiv Claire Hopkins, Mikkel Alanin, Carl Philpott, et al. Management of new onset anosmia during the COVID pandemic - BRS Consensus Guidelines. Authorea. May 22, 2020.

DOI: $10.22541 / \mathrm{au} .159015263 .38072348$

xxv Akosua Adom Agyeman, Ken L. Chin, Cornelia B. Landersdorfer, Danny Liew, Richard Ofori-Asenso,

Smell and Taste Dysfunction in Patients With COVID-19: A Systematic Review and Meta-analysis,

Mayo Clinic Proceedings,Volume 95, Issue 8,2020,Pages 1621-1631,ISSN 0025-6196,

https://doi.org/10.1016/j.mayocp.2020.05.030.

xxvi Ivens GM. Stinking mayweed. N Z J Agric. 1979;138:21-3. [Google Scholar]

${ }^{x x v i i}$ Aghili Alavi Shirazi SMH. Makhzan al-Adwiya. Edited By Shams Ardekani MR; Rahimi R; Farjadmand F. Tehran: Choogan; 2013.

xxviii Aghili Alavi Shirazi SMH. Makhzan al-Adwiya. Edited By Shams Ardekani MR; Rahimi R; Farjadmand F. Tehran: Choogan; 2013.

${ }^{x x i x}$ Aghili Alavi Shirazi SMH. Makhzan al-Adwiya. Edited By Shams Ardekani MR; Rahimi R; Farjadmand F. Tehran: Choogan; 2013

${ }^{x x x}$ Pamukov D, Achtardziev CH. 1st ed. Priroda: Bratislava; 1986. Natural pharmacy (in Slovak)

xxxi Singh O, Khanam Z, Misra N, Srivastava MK. Chamomile (Matricaria chamomilla L.): An overview. Pharmacogn Rev. 2011;5(9):82-95.

doi:10.4103/0973-7847.79103

xxxii Mericli AH. The lipophilic compounds of a Turkish Matricaria chamomilla variety with no chamazuline in the volatile oil. Int J Crude Drug Res. 1990;28:145-7. [Google Scholar]

xxxiii Singh O, Khanam Z, Misra N, Srivastava MK. Chamomile (Matricaria chamomilla L.): An overview. Pharmacogn Rev. 2011;5(9):82-95. doi:10.4103/0973-7847.79103

xxxiv Pasechnik LK. Cholagogic action of extracts prepared from wild chamomile (Matricaria chamomilla) Farmakol Toksikol. 1996;29:468-9. [PubMed] [Google Scholar]

xxxv Singh O, Khanam Z, Misra N, Srivastava MK. Chamomile (Matricaria chamomilla L.): An overview. Pharmacogn Rev. 2011;5(9):82-95. doi:10.4103/0973-7847.79103

${ }^{x x x v i}$ Fluck H. 1st ed. London: W. Foulsham and Co. Ltd; 1988. Medicinal plants and authentic guide to natural remedies. [Google Scholar]

xxxvii Fluck H. 1st ed. London: W. Foulsham and Co. Ltd; 1988. Medicinal plants and authentic guide to natural remedies. [Google Scholar]

xxxviii Singh O, Khanam Z, Misra N, Srivastava MK. Chamomile (Matricaria chamomilla L.): An overview. Pharmacogn Rev. 2011;5(9):82-95. doi:10.4103/0973-7847.79103

xxxix Singh O, Khanam Z, Misra N, Srivastava MK. Chamomile (Matricaria chamomilla L.): An overview. Pharmacogn Rev. 2011;5(9):82-95. doi:10.4103/0973-7847.79103

${ }^{\mathrm{xl}}$ Schilcher H, Kamille D. 1st ed. Germany: Wissenschaft Verlagsgesellschaft; 1987. Handbuch fur arzte, apotheker und andere naturwissenschaftler. [Google Scholar] [Ref list]

xli Gupta V, Mittal P, Bansal P, Khokra SL, Kaushik D. Pharmacological potential of Matricaria recutita-A review. Int J Pharm Sci Drug Res. 2010;2:12-6. [Google Scholar]

xlii Pino JA, Bayat F, Marbot R, Aguero J. Essential oil of Chamomilla recutita (L.) Rausch. From Iran. J Essent Oil Res. 2002;14:407-8. [Google Scholar]

xliii Pirzad A, Alyari MR, Shaliba S, Zehtab-Salmasi, Moammadi A. Essential oil content and composition of German chamomile (Matricaria chamomilla L.) at different irrigation regimes. J Agron. 2006;5:451-5. [Google Scholar]

${ }^{\text {xliv }}$ Exner J, Reichling J, Becker H. Flavonoid in Matricaria chamomile. Planta Med. 1980;39:219-30. [Google Scholar]

${ }^{\text {xlv }}$ Manday E, Szoke E, Muskath Z, Lemberkovics E. A study of the production of essential oils in chamomile hairy root cultures. Eur J Drug Metab Pharmacokinet. 1999;24:303-8. [PubMed] [Google

Scholar]

xlvi Singh O, Khanam Z, Misra N, Srivastava MK. Chamomile (Matricaria chamomilla L.): An overview. Pharmacogn Rev. 2011;5(9):82-95. doi:10.4103/0973-7847.79103

xlvii Shnitzler AC, Nolan LL, Labbe R. Screening of medicinal plants for antileishmanial and antimicrobial activity. Acta Hortic. 1996;426:235-42. [Google Scholar] 
xlviii Wagner H, Bladt S, Zgainski EM. 1st ed. Heidelberg: Springer-Verlag; 1984. Plant Drug Analysis; pp. 3234. [Google Scholar]

xlix Reichling J, Bisson W, Becker H, Schilling G. Zusammensetzung und accumulation des etherischenol in Matricaria chamomilla Radix. $2 . \quad$ Mitt. Z. Naturforsch. 1983;38:159-61. [Google Scholar]

${ }^{1}$ Kumar S, Das M, Singh A, Ram G, Mallavarapu GR, Ramesh S. J Med Aromat Plant Sci. 2001;23:61723. [Google Scholar]

li Khare CP. Indian medicinal plants-an illustrated dictionary. In: Khare CP, editor. 1st ed. New York: Springer-Verlag; 2007

lii Kobayashi Y, Nakano Y, Inayama K, Sakai A, Kamiya T. Dietary intake of the flower extracts of German chamomile (Matricaria recutita L.) inhibited compound 48/80-induced itch-scratch responses in mice. Phytomedicine. 2003;10:657-64. [PubMed] [Google Scholar]

liii Srivastava JK, Gupta S. Antiproliferative and apoptotic effects of chamomile extract in various human cancer cells. J Agric Food Chem. 2007;55:94708. [PubMed] [Google Scholar]

liv Cemek M, Kaða S, Simpek N, Büyükokuroðlu ME, Konuk M. Antihyperglycemic and antioxidative potential of Matricaria chamomilla L. in streptozotocin-induced diabetic rats. Nat Med. 2008;62:284-93. [PubMed] [Google Scholar]

lv Al-Hindawi MK, Al-Deen IH, Nabi MH, Ismail MA. Anti-inflammatory activity of some Iraqi plants using intact rats. J Ethnopharmacol. 1989;26:163-8. [PubMed] [Google Scholar]

lvi Kobayashi Y, Takahashi R, Ogino F. Antipruritic effect of the single oral administration of German chamomile flower extract and its combined effect with antiallergic agents in ddY mice. J Ethnopharmacol. 2005;101:30812. [PubMed] [Google Scholar]

lvii Nogueira JC, Diniz Mde F, Lima EO. In vitro antimicrobial activity of plants in Acute Otitis Externa. Braz J Otorhinolaryngol. 2008;74:11824. [PubMed] [Google Scholar]

lviii Ramos MF, Santos EP, Bizarri CH, Mattos HA, Padilha MR, Duarte HM. Preliminary studies towards utilization of various plant extracts as antisolar agents. Int $\mathbf{J}$ Cosmet Sci. 1996;18:87-101. [PubMed] [Google Scholar] lix Pinto SA, Bohland E, Coelho Cde P, Morgulis MS, Bonamin LV. An animal model for the study of chamomilla in stress and depression: pilot study. Homeopathy. 2008;97:141-4. [PubMed] [Google Scholar]

lx Achterrath-Tuckermann U, Kunde R, Flaskmap E, Isaac $\mathrm{O}$, Theimer $\mathrm{K}$. Pharmacological investigations with compounds of chamomile V.Investigations on the spasmolytic effect of compounds of chamomile and Kamillosan ${ }^{\circledR}$ on the isolated guinea pig ileum. Planta Med. 1980;39:38-50. [PubMed] [Google Scholar]

${ }^{\text {lxi }}$ Khayyal MT, el-Ghazaly MA, Kenawy SA, Seif-el-Nasr M, Mahran LG, Kafafi YA, et al. Antiulcerogenic effect of some gastrointestinally acting plant extracts and their combination. Arzneimittelforschung. 2001;51:545-

53. [PubMed] [Google Scholar]

lxii Amsterdam JD, Li Y, Soeller I, Rockwell K, Mao JJ, Shults J. A randomized, double-blind, placebo-controlled trial of oral Matricaria recutita (chamomile) extract therapy for generalized anxiety disorder. J Clin Psychopharmacol. 2009;29:378-82. [PMC free article] [PubMed] [Google Scholar]

lxiii Mahady GB, Pendland SL, Stoia A, Hamill FA, Fabricant D, Dietz BM, et al. In vitro susceptibility of Helicobacter pylori to botanical extracts used traditionally for the treatment of gastrointestinal disorders. Phytother Res. 2005;19:988-91. [PubMed] [Google Scholar]

lxiv Gupta AK, Misra N. Hepatoprotective activity of aqueous ethanolic extract of Chamomile capitula in paracetamol intoxicated albino rats. Am J Pharmacol Toxicol. 2006;1:17-20. [Google Scholar]

lxv Uteshev BS, Laskova IL, Afanasev V. The immunomodulating activity of the heteropolysaccharides from German chamomile (Matricaria chamomilla) during air and immersion cooling. Eksperimental'naia i Klinicheskaia Farmakologiia. 1999;62:525. [PubMed] [Google Scholar]

lxvi Vilaginès P, Delaveau P, Vilagines R. Inhibition of poliovirus replication by an extract of Matricaria chamomilla (L) Comptes Rendus de l'Academie des Sciences-III. 1985;301:289-94. [PubMed]

lxvii Sadr Lahijani MS, Raoof Kateb HR, Heady R, Yazdani D. The effect of German chamomile (Marticaria recutita L.) extract and tea tree (Melaleuca alternifolia L.) oil used as irrigants on removal of smear layer: a scanning electron microscopy study. Int Endod J. 2006;39:190-5. [PubMed]

lxviii Khater HF, Ramadan MY, El-Madawy RS. Lousicidal, ovicidal and repellent efficacy of some essential oils against 
lice and flies infesting water buffaloes in Egypt. Vet Parasitol. 2009;164:257-66. [PubMed] [Google Scholar]

${ }^{\text {lxix }}$ Kassi E, Papoutsi Z, Fokialakis N, Messari I, Mitakou S, Moutsatsou P. Greek plant extracts exhibit selective estrogen receptor modulator (SERM)-like properties. J Agric Food Chem. 2004;52:6956-61. [PubMed] [Google Scholar]

${ }^{\text {lxx }}$ Kesmati M, Abbasi Zadeh Z, Mofhaddam HF. Study of benzodiazepine like effects of Matricaria recutita on morphine withdrawal syndrome in adult male rats. Pak $\mathbf{J}$ Med Sci. 2008;24:735-9. [Google Scholar]

lxxi Bianco MI, Lúquez C, de Jong LI, Fernández RA. Presence of Clostridium botulinum spores in Matricaria chamomilla (chamomile) and its relationship with infant botulism. Int J Food Microbiol. 2008;121:35760. [PubMed] [Google Scholar]

lxxii Mazokopakis EE, Vrentzos GE, Papadakis JA, Babalis DE, Ganotakis ES. Wild chamomile (Matricaria recutita L.) mouthwashes in methotrexate-induced oral mucositis. Phytomedicine. 2005;12:25-

7. [PubMed] [Google Scholar]

lxxiii Shipochliev T. Uterotonic action of extracts from a group of medicinal plants. Veterinarno-Meditsinsiki Nauki. 1981;18:94-8. [PubMed] [Google Scholar]

lxxiv Koch C, Reichling J, Schneele J, Schnitzler P. Inhibitory effect of essential oils against herpes simplex virus type 2. Phytomedicine. 2008;15:718. [PubMed] [Google Scholar]

${ }^{\text {lxxv }}$ Martins MD, Marques MM, Bussadori SK, Martins MA, Pavesi VC, Mesquita-Ferrari RA, et al. Comparative analysis between Chamomilla recutita and corticosteroids on wound healing. An in vitro and in vivo study. Phytother Res. 2009;23:274-8. [PubMed] [Google Scholar]

lxxvi Negar Balmeh, Samira Mahmoudi, Niloofar Mohammadi, Anasik Karabedianhajiabadi,

Predicted therapeutic targets for COVID-19 disease by inhibiting SARS-CoV-2 and its related receptors,

Informatics in Medicine Unlocked,Volume 20,2020,100407,ISSN 2352-9148,

https://doi.org/10.1016/j.imu.2020.100407.

lxxvii Shadman Nemati, Fatemeh Yousefbeyk, Seyedeh Matin Ebrahimi, Ali Faghih FaghihHabibi, Maryam Shakiba, Hedieh Ramezani,Effects of chamomile extract nasal drop on chronic rhinosinusitis treatment: A randomized double blind study,American Journal of Otolaryngology,Volume 42, Issue 1,2021,102743,ISSN 0196-0709, https://doi.org/10.1016/j.amjoto.2020.102743.

lxxviii Gezici S, Sekeroglu N. Novel SARS-CoV-2 and COVID-2019 Outbreak: Current Perspectives on PlantBased Antiviral Agents and Complementary Therapy Indian $\mathrm{J}$ of Pharmaceutical Education and Research. 2020;54(3s):s442-s456.

lxxix Siahpoosh MB. Clinically Improvement in a Case of COVID-19 with Gastrointestinal Manifestations through Using Natural Therapy Based on Persian Medicine: A Case Report. Trad Integr Med. 5(3):114-117.

${ }^{\text {Ixxix }} \mathrm{Li}$, Q., Zhao, S., Lu, J. et al. Quantitative proteomics analysis of the treatment of asthma rats with total flavonoid extract from chamomile. Biotechnol Lett 42, 905-916 (2020). https://doi.org/10.1007/s10529-020-02825-0

${ }^{\operatorname{lxx} x} \mathrm{Li}$, Q., Zhao, S., Lu, J. et al. Quantitative proteomics analysis of the treatment of asthma rats with total flavonoid extract from chamomile. Biotechnol Lett 42, 905-916 (2020). https://doi.org/10.1007/s10529-020-02825-0

lxxxi El Sayed SM, Aboonq MS, El Rashedy AG, Aljehani YT, Abou El-Magd RM, Okashah AM, El-Anzi ME, Alharbi MB, El-Tahlawi R, Nabo MMH, Yousef RS, Elshazley M, Abu-Elnaga M, Mahmoud HS, El-Alaf H, Abdelrahman AI, Abdel-Gawad AR, Soliman TM. Promising preventive and therapeutic effects of TaibUVID nutritional supplements for COVID-19 pandemic: towards better public prophylaxis and treatment (A retrospective study). Am J Blood Res. 2020 Oct 15;10(5):266-282. PMID: 33224571; PMCID: PMC7675122.

lxxxii (PDF) COVID-19 PANDEMIC, UNANI MEDICINE AND IMMUNOMODULATION (researchgate.net)

Ixxxiii Rabago D, Zgierska A. Saline nasal irrigation for upper respiratory conditions. Am Fam Physician. 2009 Nov 15;80(10):1117-9. PMID: 19904896; PMCID: PMC2778074

lxxxiv Aghili Alavi Shirazi SMH. Makhzan al-Adwiya. Edited By Shams Ardekani MR; Rahimi R; Farjadmand F. Tehran: Choogan; 2013

${ }^{\text {lxxxv }}$ Aghili Alavi Shirazi SMH. Makhzan al-Adwiya. Edited By Shams Ardekani MR; Rahimi R; Farjadmand F. Tehran: Choogan; 2013

lxxxvi Brown CL, Graham SM. Nasal irrigations: good or bad?. Curr Opin Otolaryngol Head Neck Surg. 2004;12(1):9-13.

lxxxvii Rabago D, Zgierska A, Peppard P, Bamber A. The prescribing patterns of Wisconsin family physicians 
surrounding saline nasal irrigation for upper respiratory conditions. WMJ. 2009;108(3):145-150.

lxxxviii Karadag A. Nasal saline for acute sinusitis. Pediatrics. 2002;109(1):165.

lxxxix Kurtaran H, Karadag A, Catal F, Avci Z. A reappraisal of nasal saline solution use in chronic sinusitis. Chest. 2003;124(5):2036-2037.

${ }^{x c}$ Ponikau JU, Sherris DA, Kephart GM, et al. Striking deposition of toxic eosinophil major basic protein in mucus: implications for chronic rhinosinusitis. $J$ Allergy Clin Immunol. 2005;116(2):362-369.

${ }^{x c i}$ Georgitis JW. Nasal hyperthermia and simple irrigation for perennial rhinitis. Changes in inflammatory mediators. Chest. 1994;106(5):1487-1492.

xcii Boek WM, Graamans K, Natzijl H, van Rijk PP, Huizing EH. Nasal mucociliary transport: new evidence for a key role of ciliary beat frequency. Laryngoscope. 2002;112(3):570-573.

xciii Talbot AR, Herr TM, Parsons DS. Mucociliary clearance and buffered hypertonic saline solution. Laryngoscope. 1997;107(4):500-503. 